\title{
Synthesis and Characterization of Complexes of Rh(II) with Purines and Pyrimidines
}

\author{
R. ILAVARASI ${ }^{1 *}$, L. MUTHULAKSHMI ${ }^{1}$ and S. SELVANAYAGAM ${ }^{2}$ \\ ${ }^{1}$ Department of Chemistry, Kalasalingam University, Krishnankoil-626 126, India \\ ${ }^{2}$ Department Physics, Kalasalingam University, Krishnankoil-626 126, India \\ ilavarasi_chidu@yahoo.com
}

Received 8 August 20014/ Accepted 5 September 2014

\begin{abstract}
The reactions of nucleobases and aminoacids with rhodium(II) acetate resulted in the isolation of the complexes of the types $\mathrm{Rh}_{2}\left(\mathrm{CH}_{3} \mathrm{COO}\right)_{4} \mathrm{~L}\left(\mathrm{H}_{2} \mathrm{O}\right)$ and $\mathrm{Rh}_{2}\left(\mathrm{CH}_{3} \mathrm{COO}\right)_{4} \mathrm{~L}_{2}$. The binding sites of nucleobases towards rhodium(II) and the affinity of heteroatoms in nucleobases towards the metal ion were studied by various characterization techniques. Theoretical calculations have been done on the ligands such as $\mathrm{C}_{6} \mathrm{H}_{5} \mathrm{CH}_{2}$-ade, hypoxan, Cl-gua, S-gua, cyt and S-url employing modified neglect of differential overlap (MNDO) method to understand their reactivity towards the metal and to compare with the experimental results.
\end{abstract}

Keywords: Metal nucleobase complexes, TG, Electronic, ESCA studies, Theoretical studies

\section{Introduction}

There has been significant interest in the complexes of rhodium with nucleobases, nucleosides and nucleotides ${ }^{1-3}$ due to the potential antitumour activity of the compounds. Adducts of the $\mathrm{Rh}_{2}\left(\mathrm{CH}_{3} \mathrm{COO}\right)_{4} \mathrm{~L}_{2}$ where $\mathrm{L}$ is theophylline and caffeine have been prepared and the ligands occupy the axial positions and are bonded through $\mathrm{N} 9$ to $\mathrm{Rh}^{2+}$ ions ${ }^{4}$. The kinetics of the interaction of 3 glycine containing dipeptides namely Glycyl- $L$-tyrosine, glycyl- $L$-alanine and glycyl- $L$-asparagine has been studied spectrophotometrically in aqueous medium as a function of the molar concentration of $\left[\mathrm{Rh}\left(\mathrm{H}_{2} \mathrm{O}\right)_{5} \mathrm{OH}\right]^{2+}$, dipeptide, $\mathrm{pH}$ and temperature at constant ionic strengths ${ }^{5}$. The reactions studied showed that the variation in size and bulkiness of the entering dipeptides reflects their properties as nucleophiles. The $\mathrm{Rh}(\mathrm{II})$ (isobutyrate) ${ }_{4} \mathrm{~L}_{2}$, an antitumor drug ${ }^{6}$ was shown to react with nucleic acid base derivatives, $\mathrm{A}, \mathrm{G}, \mathrm{U}$ and $\mathrm{C}$ in $\mathrm{CHCl}_{3}$ solution. When these derivatives were treated with novel metal compound, the rhodium carboxylate in $\mathrm{CHCl}_{3}$ forms fairly strong complex. The metallointercalator $\mathrm{Rh}(\mathrm{Phi}) 2 \mathrm{DMB} 3+$, (Phi,9,10-phenanthrenequinone diimine :DMB, 4,4' -dimethyl -2,2'-bipyridine) catalysed the repair of a thymine dimer incorporated site specifically in a 16-base pair DNA duplex by means of visible light and is accomplished with rhodium noncovalently bound to the complex with the rhodium intercalator tethered to either end of the duplex assembly ${ }^{7}$. The present note reports the synthesis and characterization of the complexes of Rh(II) with nucleic acid derivatives. 


\section{Experimental}

Rhodium(II) complexes $\quad\left[\mathrm{Rh}_{2}\left(\mathrm{CH}_{3} \mathrm{COO}\right)_{4} \mathrm{~L}\left(\mathrm{H}_{2} \mathrm{O}\right)\right], \quad \mathrm{L}=\mathrm{Cl}$-gua, S-gua or hypoxan; $\left[\mathrm{Rh}_{2}\left(\mathrm{CH}_{3} \mathrm{COO}\right)_{4} \mathrm{~L}_{2}\right], \mathrm{L}=\mathrm{C}_{6} \mathrm{H}_{5} \mathrm{CH}_{2}$-ade, S-url or cyt have been synthesized and characterized by chemical and thermal analyses, infrared, electronic and ${ }^{1} \mathrm{H}$ NMR studies. The method of syntheses of the complexes is outlined below.

\section{Synthesis of Rh(II) Complexes}

Tetrakis - $\mu$ - acetatoaquo (6-chloroguanine-N7) dirhodium(II), $\left[\mathrm{Rh}_{2}\left(\mathrm{CH}_{3} \mathrm{COO}\right)_{4} \mathrm{C1}\right.$ $\left.\operatorname{gua}\left(\mathrm{H}_{2} \mathrm{O}\right)\right]$

Rhodium(II) acetate (1.0 mmol in $20 \mathrm{~mL}$ of $\mathrm{H}_{2} \mathrm{O}$ ) was added to an aqueous solution of Cl-gua ( $1.0 \mathrm{mmol}$ in $50 \mathrm{~mL}$ of $\mathrm{H}_{2} \mathrm{O}$ ) and stirred continuously for a day. After concentrating the reaction mixture to half of its original volume, the stirring was continued until the precipitation of the product was achieved. The resultant precipitate was filtered, washed with hot water, acetone and air-dried. Similarly the other complexes, namely, tetrakis - $\mu$ - acetatoaquo (6-thioguanine-S) dirhodium(II), $\mathrm{Rh}_{2}\left(\mathrm{CH}_{3} \mathrm{COO}\right)_{4} \quad S$-gua $\left(\mathrm{H}_{2} \mathrm{O}\right)$, tetrakis - $\mu$ - acetatoaquo (hypoxanthine-N7) dirhodium(II), $\mathrm{Rh}_{2}\left(\mathrm{CH}_{3} \mathrm{COO}\right)_{4}$ hypoxan $\left(\mathrm{H}_{2} \mathrm{O}\right)$, tetrakis- $\mu$-acetatobis(N6-benzylademine-N7) dirhodium(II), $\quad \mathrm{Rh}\left(\mathrm{CH}_{3} \mathrm{COO}\right)_{4}\left(\mathrm{C}_{6} \mathrm{H}_{5} \mathrm{CH}_{2} \text {-ade }\right)_{2}, \quad$ tetrakis- $\mu$-acetatobis(2-thiouracilato-S) dirhodium(II), $\mathrm{Rh}\left(\mathrm{CH}_{3} \mathrm{COO}\right)_{4}(\mathrm{~S}-\mathrm{ur} 1)_{2}$ and tetrakis- $\mu$-acetatobis (cytosine-O2)dirhodium(II), $\mathrm{Rh}_{2}\left(\mathrm{CH}_{3} \mathrm{COO}\right)$ (cyt) $)_{2}$ are synthesized using the corresponding nucleobases. The preparation of cytosine complex involved refluxion (8 h). Yields are in the range of 70-75\%.

\section{Results and Discussion}

\section{Rhodium(II) complexes of purines and pyrimidines}

The complexes are insoluble in water and in common organic solvents like acetone, alcohol, chloroform and benzene but are soluble in DMSO. However, $\mathrm{Rh}_{2}\left(\mathrm{CH}_{3} \mathrm{COO}\right)_{4} \mathrm{~S}$-gua $\left(\mathrm{H}_{2} \mathrm{O}\right)$ is insoluble even in DMSO. The analytical and conductivity data of the complexes are tabulated in Table 1. The complexes of Rh(II) show a molar conductance of $6-11 \mathrm{ohm}^{-1} \mathrm{~cm}^{2}$ in $10^{-3} \mathrm{M} \mathrm{DMSO}$ and indicate that the complexes are non-ionic. The compounds do not show any EPR signal suggesting them to be diamagnetic which is also confirmed by magnetic measurements in accordance with the expected dimeric nature of the rhodium(II) systems ${ }^{8}$. Thus, the complexes are possibly dimeric in nature with the bridging of the acetato group and the formation of Rh-Rh bond.

Table 1. Analytical and conductivity data of Rh(II) complexes

\begin{tabular}{|c|c|c|c|c|c|c|}
\hline $\begin{array}{l}z_{1} \\
\text { is }\end{array}$ & Complexes & $\mathrm{C} \%$ & $\mathrm{H} \%$ & N\% & $\mathrm{Rh} \%$ & $\begin{array}{c}\text { Molar } \\
\text { conductance } \\
\text { ohm }^{-1} \mathrm{~cm}^{2}\end{array}$ \\
\hline 1 & $\begin{array}{c}\mathrm{Rh}_{2}\left(\mathrm{CH}_{3} \mathrm{COO}\right)_{4} \\
\text { Cl-gua }\left(\mathrm{H}_{2} \mathrm{O}\right)\end{array}$ & 24.39 (24.80) & $2.96(2.88)$ & $10.51(11.13)$ & 33.43 (32.69) & 7 \\
\hline 2 & $\begin{array}{c}\mathrm{Rh}_{2}\left(\mathrm{CH}_{3} \mathrm{COO}\right)_{4} \\
\text { S-gua }\left(\mathrm{H}_{2} \mathrm{O}\right)\end{array}$ & 24.80 (24.89) & $2.14(3.05)$ & 10.49 (11.17) & 33.31 (32.81) & - \\
\hline 3 & $\begin{array}{l}\mathrm{Rh}_{2}\left(\mathrm{CH}_{3} \mathrm{COO}\right)_{4} \\
\text { hypoxan }\left(\mathrm{H}_{2} \mathrm{O}\right)\end{array}$ & 26.99 (26.19) & 2.19 (3.04) & $10.26(9.40)$ & 34.47 (34.53) & 6 \\
\hline 4 & $\begin{array}{l}\mathrm{Rh}_{2}\left(\mathrm{CH}_{3} \mathrm{COO}\right)_{4} \\
\left(\mathrm{C}_{6} \mathrm{H}_{5} \mathrm{CH}_{2} \text {-ade }\right)_{2}\end{array}$ & $41.21(41.41)$ & $3.12(3.91)$ & 15.15 (15.09) & $22.52(22.18)$ & 6 \\
\hline 5 & $\begin{array}{c}\mathrm{Rh}\left(\mathrm{CH}_{3} \mathrm{COO}\right)_{4} \\
(\mathrm{~S}-\mathrm{url})_{2}\end{array}$ & $26.92(27.53)$ & $1.91(2.31)$ & $8.88(8.03)$ & $29.67(29.48)$ & 6 \\
\hline 6 & $\begin{array}{c}\mathrm{Rh}_{2}\left(\mathrm{CH}_{3} \mathrm{COO}\right)_{4} \\
\text { (cyt)2 }\end{array}$ & 28.90(28.93) & 3.14 (3.33) & $12.96(12.66)$ & 29.21 (30.99) & 11 \\
\hline
\end{tabular}




\section{Thermal analysis studies}

The TGA and DTA plots of the rhodium(II) complexes are given in Figures 1 and 2. The thermoanalytical data are presented in Table 2. As seen from the plots, the complexes (1-3) start decomposing around $130{ }^{\circ} \mathrm{C}$ and about $2.9 \%$ of the initial mass is lost by $150{ }^{\circ} \mathrm{C}$. This is attributed to loss of water. Calculated weight for the dehydration of one molecule of water is $3.03 \%$ which agrees well with the observed value. This dehydration process is confirmed by endothermic peak maxima observed at $130{ }^{\circ} \mathrm{C}$ in the DTA plot. Increase in temperature, resulted in further loss in weight in the temperature range $250-415{ }^{\circ} \mathrm{C}$ and the decomposition is due to the organic moieties. The TG curves indicate that the decomposition process of acetate and nucleobase overlap though there are two distinct DTA peaks around 320 and $395{ }^{\circ} \mathrm{C}$. The final residue obtained around $410{ }^{\circ} \mathrm{C}$ is found to be $40.3 \%$ of the initial weight of the complex, which is in agreement with the calculated value of $42.11 \%$ for the formation of $\mathrm{Rh}_{2} \mathrm{O}_{3}$ which is confirmed by its powder x-ray diffraction patterns with $\mathrm{d}_{\text {hkl }}$ values 2.621, 2.725 and $2.572 \AA$ (reported values $2.623,2.722$ and $2.574 \AA$ respectively) ${ }^{9}$.

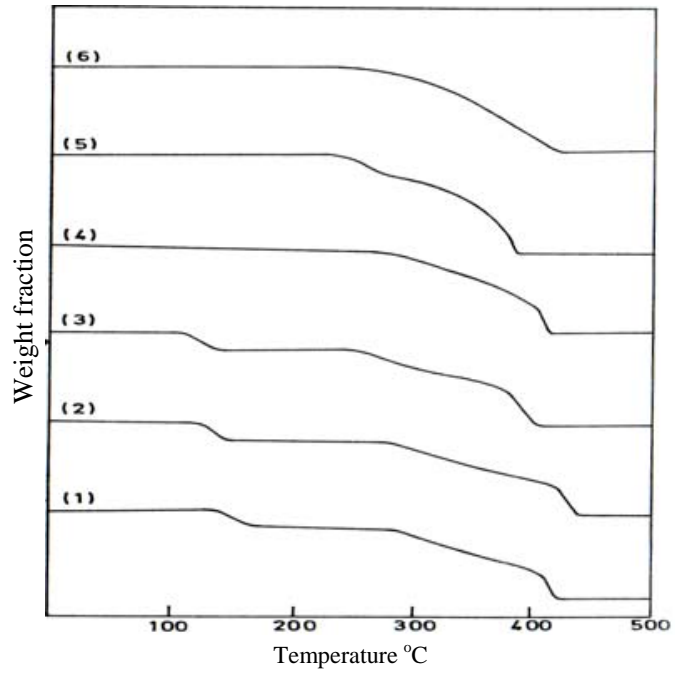

Figure 1. TG curves of $\mathrm{Rh}_{2}\left(\mathrm{CH}_{3} \mathrm{COO}\right)_{4} \mathrm{~L}$ $\left(\mathrm{H}_{2} \mathrm{O}\right), \mathrm{L}=(1) \mathrm{Cl}$-gua(2) S-gua(3) hypoxan; $\mathrm{Rh}_{2}\left(\mathrm{CH}_{3} \mathrm{COO}\right)_{4} \mathrm{~L}_{2}, \mathrm{~L}=(4) \mathrm{C}_{6} \mathrm{H}_{5} \mathrm{CH}_{2}=$ ade (5) S-url (6) cyt

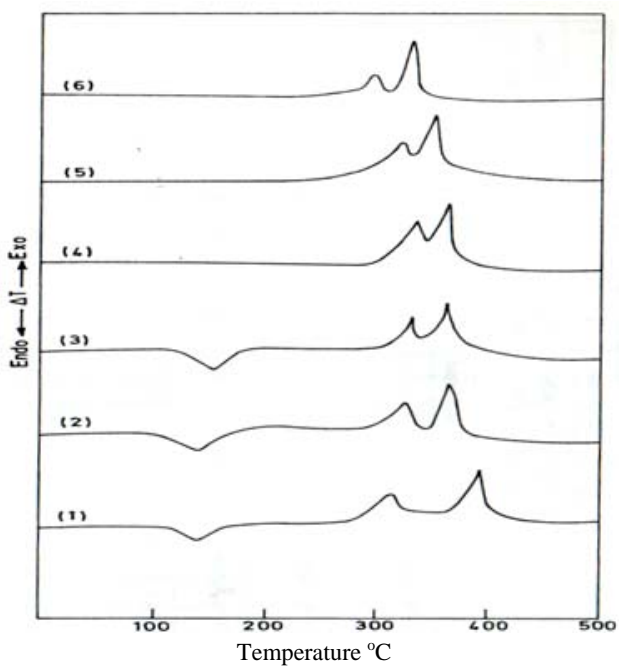

Figure 2. DTA curves of $\mathrm{Rh}_{2}\left(\mathrm{CH}_{3} \mathrm{COO}\right)_{4} \mathrm{~L}$ $\left(\mathrm{H}_{2} \mathrm{O}\right), \mathrm{L}=(1) \mathrm{Cl}$-gua(2) S-gua(3) hypoxan; $\mathrm{Rh}_{2}\left(\mathrm{CH}_{3} \mathrm{COO}\right)_{4} \mathrm{~L}_{2}, \mathrm{~L}=$ (4) $\mathrm{C}_{6} \mathrm{H}_{5} \mathrm{CH}_{2}=\operatorname{ade}(5)$ S-url (6) cyt

Table 2. Thermoanalytical data of Rh(II) complexes

\begin{tabular}{|c|c|c|c|c|c|c|c|c|c|}
\hline \multirow{3}{*}{$\begin{array}{l}\dot{z} \\
\dot{s}\end{array}$} & \multirow{3}{*}{ Complexes } & \multicolumn{4}{|c|}{ Dehydration } & \multicolumn{4}{|c|}{ Formation of $\mathrm{Rh}_{2} \mathrm{O}_{3}$} \\
\hline & & \multirow{2}{*}{$\begin{array}{l}\text { Temp. } \\
\text { range }{ }^{\circ} \mathrm{C}\end{array}$} & \multicolumn{2}{|c|}{$\begin{array}{c}\text { Weight loss, } \\
\% \\
\end{array}$} & \multirow{2}{*}{ 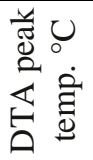 } & \multirow{2}{*}{$\begin{array}{l}\text { Temp. } \\
\text { range } \\
{ }^{\circ} \mathrm{C}\end{array}$} & \multicolumn{2}{|c|}{ Weight loss, \% } & \multirow{2}{*}{$\begin{array}{l}\text { DTA Peak } \\
\text { Temp. }{ }^{\circ} \mathrm{C}\end{array}$} \\
\hline & & & Calc. & Found & & & Calc. & Found & \\
\hline 1 & $\begin{array}{c}\mathrm{Rh}_{2}\left(\mathrm{CH}_{3} \mathrm{COO}\right)_{4} \\
\text { (C1-gua) }\left(\mathrm{H}_{2} \mathrm{O}\right)\end{array}$ & $130-150$ & 3.03 & 2.9 & -130 & $290-410$ & 57.89 & 59.7 & $\begin{array}{l}+320 \\
+395\end{array}$ \\
\hline 2 & $\begin{array}{c}\mathrm{Rh}_{2}\left(\mathrm{CH}_{3} \mathrm{COO}\right)_{4} \\
(\mathrm{~S} \text {-gua })\left(\mathrm{H}_{2} \mathrm{O}\right)\end{array}$ & $125-140$ & 3.13 & 2.9 & -130 & $280-415$ & 58.12 & 59.5 & $\begin{array}{r}+330 \\
+375 \\
\end{array}$ \\
\hline
\end{tabular}




\begin{tabular}{|c|c|c|c|c|c|c|c|c|c|}
\hline 3 & $\begin{array}{l}\mathrm{Rh}_{2}\left(\mathrm{CH}_{3} \mathrm{COO}\right)_{4} \\
\text { (hypoxan) }\left(\mathrm{H}_{2} \mathrm{O}\right)\end{array}$ & $125-140$ & 3.04 & 3.0 & -135 & $250-400$ & 58.13 & 57.4 & $\begin{array}{l}+330 \\
+370\end{array}$ \\
\hline 4 & $\begin{array}{c}\mathrm{Rh}_{2}\left(\mathrm{CH}_{3} \mathrm{COO}\right)_{4} \\
\left(\mathrm{C}_{6} \mathrm{H}_{4} \mathrm{O}_{2} \text {-ade }\right)_{2}\end{array}$ & - & - & - & - & 270-405 & 71.19 & 72.7 & $\begin{array}{l}+330 \\
+355\end{array}$ \\
\hline 5 & $\begin{array}{c}\mathrm{Rh}_{2}\left(\mathrm{CH}_{3} \mathrm{COO}\right)_{4} \\
(\mathrm{~S}-\mathrm{url})_{2}\end{array}$ & - & - & - & - & $250-390$ & 63.12 & 63.6 & $\begin{array}{l}+310 \\
+360\end{array}$ \\
\hline 6 & $\begin{array}{c}\mathrm{Rh}_{2}\left(\mathrm{CH}_{3} \mathrm{COO}\right)_{4} \\
(\mathrm{Cyt})_{2}\end{array}$ & - & - & - & - & $250-400$ & 61.78 & 61.8 & $\begin{array}{l}+310 \\
+350\end{array}$ \\
\hline
\end{tabular}

- endotherm, + exotherm

The TG curves of the complexes 4,5 and 6 of type $\left[\mathrm{Rh}_{2}\left(\mathrm{CH}_{3} \mathrm{COO}\right)_{4} \mathrm{~L}_{2}\right], \mathrm{L}=\mathrm{C}_{6} \mathrm{H}_{5} \mathrm{CH}_{2}-$ ade, S-url or cyt suggest that the complexes decompose in the temperature range 250 to $405^{\circ} \mathrm{C}$ with exothermic peak maxima around 310 and $360{ }^{\circ} \mathrm{C}$. The observed weight losses are in good agreement with those of calculated weights for the formation of $\mathrm{Rh}_{2} \mathrm{O}_{3}$. The different slopes of the decompositions curves and two prominent exothermic peaks suggest that the decomposition occurs with different rates.

\section{Electronic spectral studies}

The UV-visible absorption spectra of the complexes were recorded in solution medium and as nujol mull with insoluble complexes. Rhodium(II) acetate exhibits absorption bands around 584 and $450 \mathrm{~nm}$ in $10^{-3} \mathrm{M}$ DMSO and are assigned to dimeric Rh-Rh and $\mathrm{Rh}-\mathrm{OOCCH}_{3}$ interactions ${ }^{10}$. The rhodium(II) complexes isolated in the present study show absorption bands at lower wavelength around $500 \mathrm{~nm}$. In general, the band seen at lower wavelength indicates the adduct formation by the replacement of water molecules in the axial position. The bands around $290 \mathrm{~nm}$ observed in the complexes are assigned to $\pi \rightarrow \pi^{*}$ of nucleobases in the complexes.

\section{Infrared spectral studies}

The characteristic infrared frequencies with the probable assignments are tabulated in Table 3. The infrared spectra of the complexes are compared with those of nucleobases ${ }^{11}$ and rhodium(II) acetato complexes in order to find out the mode of nucleobase bonding to rhodium. The vibrational frequencies due to the pyrimidine ring of nucleobases $\left(\mathrm{C}_{6} \mathrm{H}_{5}\right.$-ade, Cl-gua and hypoxan) appear in the same region as in the spectra of complexes indicating the noninvolvement of the pyrimidine nitrogens in bonding. On the other hand, the bands around 1430, 1345 and $1310 \mathrm{~cm}^{-1}$ in $\mathrm{C}_{6} \mathrm{H}_{5} \mathrm{CH}_{2}$-ade, $\mathrm{Cl}$-gua and hypoxan are assigned to the vibrational modes of imidazole moiety and these are located around 1410, 1335 and $1310 \mathrm{~cm}^{-1}$ in the complexes, which is suggestive of coordination through imidazole nitrogen N7. The vibrational frequencies of $S$-gua at 1590, 1535, 1480, 1425 and $1330 \mathrm{~cm}^{-1}$ due to pyrimidine and imidazole moieties appear nearly at the same positions in the spectra of the complexes which indicate the absence of coordination of ring nitrogen atoms to rhodium(II). Strong absorption at $1550 \mathrm{~cm}^{-1}$ in $S$-gua has been assigned to $v_{\text {cs }}$ and it undergoes a shift to lower wave numbers by $15 \mathrm{~cm}^{-1}$ in the complex suggesting the sulfur coordination to the metal.

In free cytosine, the absorption at $1675 \mathrm{~cm}^{-1}$ is assigned to $v_{\text {co }}$ and strong absorptions at 1615, 1590, 1512 and $1480 \mathrm{~cm}^{-1}$ are assigned to the ring vibrations. The latter set of bands are not affected much in the spectra of complexes while $v_{\text {co }}$ undergoes a negative shift of $25 \mathrm{~cm}^{-1}$ suggesting coordination to the metal through the exocyclic oxygen, $\mathrm{O}_{2}$. In the $S$-url complex ${ }^{12}$, the bands due to $v_{\mathrm{NH}}$ and $\mathrm{v}_{\mathrm{NH}}$ observed around 3100 and $700 \mathrm{~cm}^{-1}$ respectively are observed in the same region as in the ligand spectrum, but the intensities of the bands are found to be lowered suggesting that the NH groups are not deprotonated. The band at $1672 \mathrm{~cm}^{-1}$ 
due to $v_{\mathrm{c}=\mathrm{o}}$, is located at more or less in the same position as that of the ligand indicating the non-involvement of its coordination to the metal. The characteristic thiocarbonyl frequencies at 1550, 1160 and $805 \mathrm{~cm}^{-1}$ underwent negative shifts by about $20 \mathrm{~cm}^{-1}$ confirming sulphur coordination in the complex. Thus from the infrared studies, it is observed that in the complexes of type $\mathrm{Rh}_{2}\left(\mathrm{CH}_{3} \mathrm{COO}\right)_{4} \mathrm{~L}\left(\mathrm{H}_{2} \mathrm{O}\right)$ where $\mathrm{L}=\mathrm{Cl}$-gua and hypoxan, the coordination is through N7 and through $\mathrm{S} 6$ in $\mathrm{Rh}_{2}\left(\mathrm{CH}_{3} \mathrm{COO}\right)_{4}(\mathrm{~S}$-gua $)\left(\mathrm{H}_{2} \mathrm{O}\right)$. In complexes of type $\mathrm{Rh}_{2}\left(\mathrm{CH}_{3} \mathrm{COO}\right)_{4} \mathrm{~L}_{2}$, the coordination of the nucleobases is through N7, where $\mathrm{L}=\mathrm{C}_{6} \mathrm{H}, \mathrm{CH}_{2}-$ ade, through $\mathrm{S} 2$ where $\mathrm{L}=\mathrm{S}$-url, through $\mathrm{O} 2$ when $\mathrm{L}=$ cyt. In the far infrared spectra of the complexes, the weak absorption at around $520 \mathrm{~cm}^{-1}$ is assigned to $v_{\mathrm{Rh}-\mathrm{N}}$ and the band at 450 and $390 \mathrm{~cm}^{-1}$ are assigned to and $v_{\mathrm{Rh}-\mathrm{s}}$ respectively ${ }^{10}$.

Table 3. Principal infrared spectral data of rhodium(II) complexes $\left(\mathrm{cm}^{-1}\right)$

\begin{tabular}{|c|c|c|c|c|c|c|c|c|c|}
\hline$i_{i}^{\circ}$ & 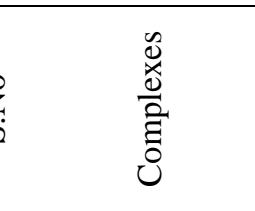 & 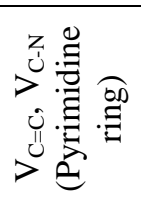 & 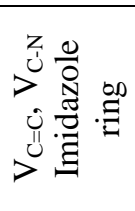 & $>^{2} \bigcirc$ & $>^{\text {ह }}$ & 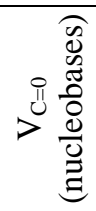 & 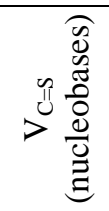 & 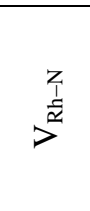 & $\begin{array}{c}0 \\
\frac{1}{\frac{1}{n}} \\
p^{0} \\
0 \\
\frac{1}{x} \\
p^{\frac{1}{n}}\end{array}$ \\
\hline \multirow{2}{*}{\multicolumn{2}{|c|}{$\begin{aligned} 1 \mathrm{Rh}_{2}\left(\mathrm{CH}_{3} \mathrm{COO}\right)_{4} \\
\quad(\mathrm{Cl} \text {-gua })\left(\mathrm{H}_{2} \mathrm{O}\right)\end{aligned}$}} & $1579 m$ & $1420 m$ & $1592 \mathrm{~s}$ & $1430 \mathrm{~s}$ & --- & --- & $521 \mathrm{~m}$ & $460 \mathrm{~m}$ \\
\hline & & $1550 \mathrm{~m}$ & $\begin{array}{c}1335 \mathrm{~m} \\
1300 \mathrm{~s}\end{array}$ & & & & & & \\
\hline \multirow{2}{*}{\multicolumn{2}{|c|}{$\begin{aligned} 2 \mathrm{Rh}_{2}\left(\mathrm{CH}_{3} \mathrm{COO}\right)_{4} \\
\quad(S \text {-gua })\left(\mathrm{H}_{2} \mathrm{O}\right)\end{aligned}$}} & $1574 \mathrm{~m}$ & $1430 \mathrm{~m}$ & $1590 \mathrm{~s}$ & $1430 \mathrm{~s}$ & -- & $1525 \mathrm{~m}$ & --- & $450 w, 380 m$ \\
\hline & & $1547 \mathrm{~m}$ & $\begin{array}{l}1430 \mathrm{~s} \\
1320 \mathrm{~s} \\
1300 \mathrm{w}\end{array}$ & & & & & & \\
\hline \multirow{2}{*}{\multicolumn{2}{|c|}{$\begin{array}{r}3 \mathrm{Rh}_{2}\left(\mathrm{CH}_{3} \mathrm{COO}\right)_{4} \\
\quad \text { (hypoxan) }\left(\mathrm{H}_{2} \mathrm{O}\right)\end{array}$}} & $1589 m$ & 14 I 5m & $1590 \mathrm{~s}$ & 141 Is & $1680 \mathrm{~s}$ & --- & $512 \mathrm{~s}$ & $450 \mathrm{~s}$ \\
\hline & & $1552 \mathrm{~m}$ & $\begin{array}{l}1327 m \\
1310 w\end{array}$ & & & & & & \\
\hline \multirow{2}{*}{\multicolumn{2}{|c|}{$\begin{array}{r}4 \mathrm{Rh}_{2}\left(\mathrm{CH}_{3} \mathrm{COO}\right)_{4} \\
\quad\left(\mathrm{C}_{6} \mathrm{H}_{5} \mathrm{CH}_{2} \text {-ade }\right)_{2}\end{array}$}} & $1571 \mathrm{~s}$ & $1405 \mathrm{~m}$ & $1590 \mathrm{~s}$ & $1427 \mathrm{~s}$ & --- & --- & $512 \mathrm{~s}$ & $440 \mathrm{~s}$ \\
\hline & & $1531 \mathrm{~s}$ & $\begin{array}{c}1327 \mathrm{~m} \\
1293 \mathrm{~s}\end{array}$ & & & & & & \\
\hline \multirow{2}{*}{\multicolumn{2}{|c|}{$\begin{aligned} 5 \mathrm{Rh}_{2}\left(\mathrm{CH}_{3} \mathrm{COO}\right)_{4} \\
\quad(S \text {-url })_{2}\end{aligned}$}} & $1520 \mathrm{~s}$ & --- & $1590 \mathrm{~s}$ & $1435 \mathrm{~s}$ & $1672 \mathrm{~s}$ & $1530 \mathrm{~m}$ & --- & 4505 \\
\hline & & $1480 \mathrm{~s}$ & & & & & $1145 w$ & & $390 \mathrm{~s}$ \\
\hline \multirow{2}{*}{\multicolumn{2}{|c|}{$\begin{array}{l}6 \mathrm{Rh}_{2}\left(\mathrm{CH}_{3} \mathrm{COO}\right)_{4} \\
\quad(\text { cyt })_{2}\end{array}$}} & $1520 \mathrm{~s}$ & --- & $1600 \mathrm{~s}$ & $1425 \mathrm{~s}$ & $1675 \mathrm{~s}$ & --- & --- & $440 \mathrm{~s}$ \\
\hline & & $1478 \mathrm{~m}$ & & & & & & & \\
\hline
\end{tabular}

NMR spectral studies

The ${ }^{1} \mathrm{H}$ NMR spectral data of the complexes are given in Table 4. The NMR spectra assist in evaluating the binding site(s) of the ligands. The ${ }^{1} \mathrm{H}$ NMR spectrum of free $\mathrm{C}_{6} \mathrm{H}_{5} \mathrm{CH}_{2}$-ade in $\mathrm{d}_{6}$-DMSO exhibits two singlets at 7.88 and $8.10 \mathrm{ppm}$ corresponding to $\mathrm{H} 2$ and $\mathrm{H} 8$ resonances respectively. In the complex $\mathrm{Rh}_{2}\left(\mathrm{CH}_{3} \mathrm{COO}\right)_{4}\left(\mathrm{C}_{6} \mathrm{H}_{5} \mathrm{CH}_{2} \text {-ade }\right)_{2}$, the H8 resonance is observed at $8.25 \mathrm{ppm}$ and the downfield shift of $\mathrm{H} 8$ by $0.15 \mathrm{ppm}$ indicates the coordination of $\mathrm{C}_{6} \mathrm{H}_{5} \mathrm{CH}_{2}$-ade to the metal ${ }^{13}$ through N7. The same trend is seen in hypoxan 
and Cl-gua complexes. Thus, the NMR data confirm the coordination of N7 to rhodium(II). The spectrum of cytosine in $\mathrm{d}_{6}$-DMSO exhibits two doublets at 6.4 and $7.28 \mathrm{ppm}$ due to $\mathrm{H} 5$ and $\mathrm{H} 6$ resonances, which do not shift their positions in the spectrum of the complex.

Table 4. Proton NMR data of Rh(II) complexes (TMS - standard, solvent - $\mathrm{d}_{6}$ - DMSO)

\begin{tabular}{clcccc}
\hline \multirow{2}{*}{ S.No } & \multirow{2}{*}{ Complexes } & \multicolumn{3}{c}{$\begin{array}{c}\text { Acetate Protons } \\
(8 \text { in ppm })\end{array}$} & \multicolumn{2}{c}{ Nucleobase Protons (8 in ppm) } \\
\cline { 3 - 6 } & & 2.12 & 8.01 & - & 12.08 \\
\hline \multirow{2}{*}{1} & $\mathrm{Rh}_{2}\left(\mathrm{CH}_{3} \mathrm{COO}\right)_{4}(\mathrm{Cl}$-gua $)\left(\mathrm{H}_{2} \mathrm{O}\right)$ & & $\mathrm{H} 5 / \mathrm{H} 8$ & $\mathrm{H} 6 / \mathrm{H} 2$ & $\mathrm{NH} / \mathrm{NH}_{2}$ \\
2 & $\mathrm{Rh}_{2}\left(\mathrm{CH}_{3} \mathrm{COO}\right)_{4}($ hypoxan $)\left(\mathrm{H}_{2} \mathrm{O}\right)$ & 2.12 & 8.31 & 8.0 & 12.05 \\
3 & $\mathrm{Rh}_{2}\left(\mathrm{CH}_{3} \mathrm{COO}\right)_{4}\left(\mathrm{C}_{6} \mathrm{H}_{5} \mathrm{CH}_{2} \text {-ade }\right)_{2}$ & 2.10 & 8.25 & 7.96 & - \\
4 & $\mathrm{Rh}_{2}\left(\mathrm{CH}_{3} \mathrm{COO}\right)_{4}(\mathrm{cyt})_{2}$ & 2.11 & 6.40 & 7.28 & 12.08 \\
\hline
\end{tabular}

\section{$X$-ray photoelectron spectroscopic studies}

The XPS spectra of the $\mathrm{Rh}_{2}\left(\mathrm{CH}_{3} \mathrm{COO}\right)_{4}\left(\mathrm{C}_{6} \mathrm{H}_{5} \mathrm{CH}_{2}\right.$-ade) in the 3d region of Rh (Figure 4a), $\mathrm{O}_{1 \mathrm{~s}}$ region of acetate (Figure $4 \mathrm{~b}$ ) and $\mathrm{N}_{1 \mathrm{~s}}$ region of $\mathrm{C}_{6} \mathrm{H}_{5} \mathrm{CH}_{2}$-ade (Figure $4 \mathrm{c}$ ) are shown. The rhodium $3 \mathrm{~d}_{5 / 2}$ and $3 \mathrm{~d}_{3 / 2}$ core level binding energies are found to be 309.0 and $313.3 \mathrm{eV}$ respectively. The energy separation between rhodium spin-orbit doublet levels is $4.3 \mathrm{eV}^{14}$. Thus the sharp peak at $313.3 \mathrm{eV}$ shows the presence of one type of rhodium atom. A single $01 \mathrm{~s}$ peak at $533.2 \mathrm{eV}$ indicates the equivalent oxygen atoms in the complex. Three peaks are observed at 397.0, 397.5 and $397.9 \mathrm{eV}$ with an intensity ratio of 2:2:1. In the complex, similar results are observed with a higher shift $(0.5 \mathrm{eV})$ in the binding energy of N7. This suggests $\mathrm{N} 7$ coordination of $\mathrm{C}_{6} \mathrm{H}_{5} \mathrm{CH}_{2}$-ade to $\mathrm{Rh}(\mathrm{II})$.
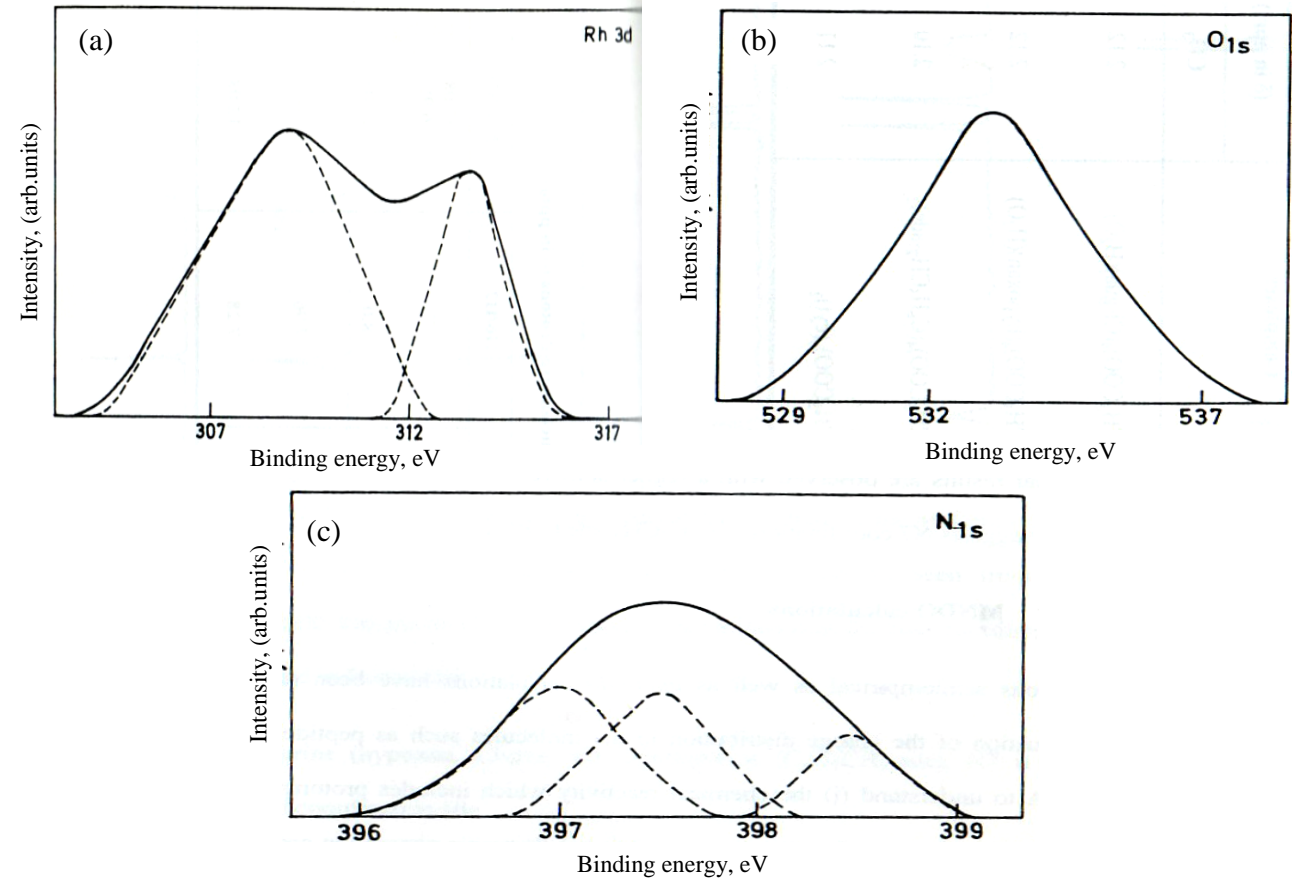

Figure 4. X-Ray photoelectron spectra (a) 3d region of Rh, (b) O1s region of acetate and (c) N1s region of $\mathrm{C}_{6} \mathrm{H}_{5} \mathrm{CH}_{2}$-ade 


\section{MNDO calculations}

Various semiempirical as well as ab initio calculations have been reported for the evaluation of the charge distribution in the molecules such as peptides, proteins and DNA to understand (i) the chemical reactivity which includes protonation, alkylation and metallation, (ii) the observed experimental electronic absorption spectra and x-ray photoelectron spectra, (iii) the energy requirement for the interconversion of the various possible tautomeric forms and (iv) the structure and functions of DNA .

In the MNDO calculations, the various interatomic distances, bond angles and dihedral angles of the molecules are needed for the calculation of the cartesian coordinates which are arrived from the geometry of the molecules after optimization. The optimization of geometry is done by using PC MODEL. The trend in the values of charge densities calculated in the present studies are employed to support the assignments of the bands observed in the XPS spectra and to understand the ligating properties of the molecules to metals. The molecules studied are (1) $\mathrm{C}_{6} \mathrm{H}_{5} \mathrm{CH}_{2}$-ade (2) hypoxan (3) Cl-gua (4) S-gua (5) Cyt and (6) $S$-url.

Table 5 gives the charge densities at various nitrogen and sulfur sites of the molecules. The complex $\mathrm{Rh}_{2}\left(\mathrm{CH}_{3} \mathrm{COO}\right)_{4}\left(\mathrm{H}_{2} \mathrm{O}\right)_{2}$ add one or two ligand molecules and the experimental studies indicated various coordination sites in the molecule to rhodium(II).

Table 5. Atomic charges at the various nitrogen and Sulfur sites of different ligands

\begin{tabular}{clccccc}
\hline S.No. & \multicolumn{1}{c}{ Molecules } & N1 & N3 & N7 & N9 & S/O \\
\hline 1 & N6-Benzyladenine & -0.34 & -0.24 & -0.17 & -0.28 & - \\
2 & Hypoxanthine & -0.39 & -0.28 & -0.15 & -0.22 & - \\
3 & 6-Chloroguanine & -0.30 & -0.29 & -0.30 & -0.26 & - \\
4 & 6-Thioguanine & -0.2 & -0.30 & -0.32 & -0.23 & -0.11 \\
5 & Cytosine & -0.36 & -0.36 & -0.36 & - & -0.19 \\
6 & 2-Thiouracil & -0.32 & -0.36 & -0.32 & - & -0.18 \\
\hline
\end{tabular}

The results indicate that the $\mathrm{N} 1$ site is the most electron rich and the order is found to be N1 > N3 > N9 > N7> O, S. Therefore, it is expected that N1 may be the preferred metal binding site in these molecules. In the present study, it may be seen from the experimental results that purines and pyrimidines use various sites for their coordination to rhodium(II) and indicated that in oxopurine (hypoxan, Cl-gua) and aminopurine $\left(\mathrm{C}_{6} \mathrm{H}_{5} \mathrm{CH}_{2}\right.$-ade), N7 is the preferred coordination site whereas $\mathrm{O} 2$ in cytosine, sulfur in $S$-gua and $S$-url are the preferred coordinating sites. From the MNDO results, it is seen that N7 in purines, O2 and S in pyrimidines are favourable electronically for the binding to rhodium(II).

\section{Conclusion}

The nucleobases $\left(\mathrm{C}_{6} \mathrm{H}_{5} \mathrm{CH}_{2}\right.$-ade, Cl-gua and hypoxan) bind to rhodium through $\mathrm{N} 7$ and the thio-nucleobases (S-url and $S$-gua) through sulfur and cytosine through $\mathrm{O} 2$. The adenine derivative $\left(\mathrm{C}_{6} \mathrm{H}_{5} \mathrm{CH}_{2}\right.$-ade) and pyrimidine nucleobases ( $\mathrm{S}$-url and cyt) are found to occupy the axial positions of square plane of each rhodium(II) formed by the bridging of acetate, whereas the guanine derivatives (Cl-gua, $S$-gua and hypoxan) occupy one of the axial sites and the other by a water molecule. Rhodium(II) appears to have a greater affinity towards sulfur atom than other heteroatoms.

\section{References}

1. Mahnkein R E, Billadu M A, Nikonowicz E P and Morrison H, J Am Chem Soc., 1992, 114(4), 9253-9265; DOI:10.1021/ja00050a002 
2. Helen T, Chifotides and Kim R Dunbar, Accoun Chem Res., 2005, 38(2), 146-156; DOI:10.1021/ar0302078

3. Lusty J R, Peeling J and Aal M A A, Inorg Chim Acta, 1981, 56, 21-26; DOI: 10.1016/S0020-1693(00)88542-4

4. Farrelli N, J Chem Soc Chem Commun., 1980, 1014-1016.

5. Bilap K Bara, Sumon Ray, Subala Mandal, Parnajyoti Karmakar and Anup Mandal, J Chem., 2013, Article ID 801362; DOI: 10.1155/2013/801362

6. Byung Sul Yu and Bak Kwangkim, Arch Pharm Res., 1978, 1, 1.

7. Dandliker P J, Holmin R E and Barton J K, Science, 1997, 275, 1465.

8. Pasternak H and Pruchnik F, Inorg Nucl.Chem Lett., 1976, 12(8), 591-598; DOI: 10.1016/0020-1650(76)80075-X

9. Geetika Borah and Devajani Boruah, Indian J Chem., 2013, 52A, 334-341.

10. Boyar E B and Robinson S.D, Coord Chem Res., 1983, 50(1-2), 109-208; DOI: 10.1016/0010-8545(83)85028-0

11. Beaumont K P and McAuliffe C A, Inorganica Chimica Acta, 1977, 24, 241.

12. Nelson H C and Vlla J F, J Inorg Nucl Chem., 1980, 42(11), 1669-1672; DOI: 10.1016/0022-1902(80)80340-X

13. Mihály T, Garijo Añorbe M, Albertí F M, Sanz Miguel P J and Lippert B, Inorg Chem., 2012, 51(19), 10437-10446; DOI:10.1021/ic301681f

14. Briggis D and Seah M B, Practical surface analysis. John Wiley and Sons, New York, 1983. 